ISSN: 2162-3104 Print/ ISSN: 2166-3750 Online

Volume 8, Issue 2 (2018), pp. 843-860

(C) Journal of International Students

http://jistudents.org/

doi: $10.5281 /$ zenodo. 1250385

\title{
The Relation of an International Student Center's Orientation Training Sessions with International Students' Achievement and Integration to University
}

Meltem Acar Güvendir

Trakya University, Turkey

\begin{abstract}
The purpose of the research is to examine the relation of orientation training sessions with integration and achievement of the international students. The study used the Institutional Integration Scales, developed by Pascarella and Terenzini (1980), to examine the integration level of the international students. 181 freshmen undergraduate and graduate international students who study at an American university filled out the scales in June 2015. According to the results, the scale's factor scores vary depending on the frequency of using the center. The students' GPA scores did not vary with regard to whether the students benefited from the center frequently or not. The study findings show that the frequency of using the center is important on integration to university.
\end{abstract}

Keywords: achievement, integration, international students, and international student center

Orientation training is done in order to assist students' integration to the university and to accelerate this process by transferring adequate information to the students (Ceyhan, 1995). Orientation training sessions contribute to the academic and social success of international students, and also to the education of the domestic students, and faculty and staff who 
work with them. A good orientation training could reduce the number of difficulties that new international students might face and could speed their adaptation to the new academic system (Althen, 1990).

A well-organized orientation training helps students construct a positive first impression of university education. The burdens of miscommunication and misunderstanding can be avoided by providing high motivation through the orientation training. Also, the students can be informed about various roles and responsibilities in the new environments. The primary purpose of orientation training is to minimize the difficulties that students may encounter, and assist them in terms of integration and the prevention of loneliness and desperateness during their transition. Thus, students are expected to become more successful and gratified as long as they adapt to their new environment in a very short time. In this regard, there are protective and preventive functions of orientation training as well as the adaptive function (Yeşilyaprak, 2005).

In general, international student orientation training includes four parts. The first part focuses on culture. In this module on culture, the goals are making students familiarize with the target culture, examine the effect of the culture, and raise a cultural awareness (Kağıtçıbaşı, 2000). The similarities and differences between the own culture of the students and the target culture are presented by describing the new cultural environment that the students are going to have access to. Students are informed about day- to -day activities such as accommodation and public transportation (Coleman \& Carsky, 1994). The second part of the international student orientation training is the cultural interaction experience. When students interact with the new culture, they can experience culture shock. This situation can foster unhappiness, loneliness or disappointment for them. In this part, the ways of coping with the stressful situation that was caused by cultural shock and the experiences that were gained during this process are addressed. The last part is related to the new opportunities and experiences of the students during their acculturation process. These opportunities and experiences can be easy and unproblematic for the students if their acculturation progresses efficiently (Berry, 1997).

The orientation training provides new students with time to rest before the opening of classes, time to practice a second language as it is used locally, time to learn their way around the local area, and time to establish some relationships with other people. The orientation sessions also 
clarify the roles and responsibilities of the international student center, and the role of the international student within the school (Althen, 1990).

The universities work to raise highly gifted people for the purpose of development. For these reasons, the universities that are responsible for raising qualified manpower are supposed to help students gain knowledge, skills, and ideally good habits. The orientation training sessions should be organized for solving the particular problems of the freshmen students who leave their families and environment for the first time, and are unable to establish new friendships and adapt to school (Korkmaz, 2000).

It is possible to encounter studies that were conducted on international students' problems about their achievement and integration procedures. Esentürk-Ercan (1998) stated that international students face problems that were caused by stress during their transition to a new culture. Other points that were addressed are the socio-cultural integration of the international Asian students (Li \& Gasser, 2005), the psychological integration of the international students who study in the U.S. (Zhang \& Goodson, 2011), the socio-cultural problems of the international students (Alazzi, \& Al-Jarrah, 2016; Kıroğlu, Kesten, \& Elma, 2010), international students' problems and their academic achievement (Alazzi, \& Al-Jarrah, 2016; Chen \& Razek, 2016; Eze \& Inegbedion, 2015; Kılıçlar, Sarı, \& Seçilmiş, 2012; Shafaei, Nejati, Quazi, \& von der Heidt, 2016), social support and integration of the Turk origin students who come from European countries to Turkey (Traş \& Güngör, 2011), organizational integration of the university students (Can, 1996), international students' social adjustment and institutional attachment (Hwang, Martirosyan, \& Moore 2015; Kaczmarek, Matlock, Merta, Ames, \& Ross, 1994; Schartner, 2015), the integration and communication problems of the students who come from Turkic Republics, Turkic and relative communities to Turkey (Çöllü \& Öztürk, 2009), and the effect of the orientation training on international students' achievement (Koç, Avşaroğlu \& Sezer, 2004; Tutar, 2002).

The orientation training in the counseling and guidance centers is carried out in order to provide service and assistance for the students who are new to university or college education in the U.S. It is thought that these services will help the new students to solve the problems they may run into and accelerate their integration process which will finally have a positive impact on their academic achievement (Henriksen, 1995). These services are provided for both students who are the U.S. citizens and the international 
students at the guidance centers within the university campuses (Mori, 2000; Pedersen, 1991).

The orientation training sessions for the international students in the international student center exist and work effectively at the U.S. universities (Guidry Lacina, 2002). However, the achievement and school integration of the students using these centers have not been examined sufficiently. Hence, examining the relation of orientation training sessions with integration and achievement of international students to the university are considered as necessary.

The purpose of the research is to determine the relation of orientation training sessions with integration and achievement of the international students.

In this sense, the research aims to answer the following questions:

- Does the frequency of the students' using the international student center orientation training sessions have a relation with their university integration?

- Does the frequency of the students' using the international student center orientation training sessions have a relation with their academic achievement?

\section{RESEARCH METHOD}

Correlational survey research was used for this study. According to Creswell (2012), investigators use correlational statistics to describe and measure the degree or association between two or more variables or sets of scores in correlational research. This research has been elaborated into more complex relationships among variables (Creswell, 2014). Also, Fraenkel and Wallen (2000) said, "Correlational research is an example of what is sometimes called associational research. In associational research, the relationships among two or more variables are studied without any attempt to influence them" (p. 359).

The Institutional Integration Scales, developed by Pascarella and Terenzini (1980), were used for determining the integration level of the international students. These scales were constructed upon Tinto's (1975) model. In that model, the integrations of the students are measured on five factors based on the concepts (a) academic integration, (b) institutional perception, (c) social integration, (d) goal commitment, and (e) institutional 
commitment. The Institutional Integration Scales measure social and academic integration concepts multi-dimensionally, and predict whether the freshman students continue their education at the same university or not during the following years of their education. According to the validity and reliability of the scale from different studies (Pascarella \& Terenzini, 1980; Terenzini, Lorang, \& Pascarella, 1981) cronbach alpha coefficients were found to be between .69 and .84 . According to the subscale, coefficients were .84 and .84 for Peer-Group Interactions, .83 and .83 for Interactions with Faculty; .82 and.71 for Faculty concern for Student Development and Teaching; .74 and .69 for Academic and Intellectual Development; .71 and .58 for Institutional and Goal Commitments. Also, explanatory factor analysis showed five factors structure that explains $44.4 \%$ of the total variance at the first step, $44.6 \%$ of total variance at the second step.

In this study, Cronbach alpha and split half reliabilities were used to determine reliability coefficients. Cronbach alpha coefficients were found .82 for Academic and Intellectual Development (AID), .87 for Peer-Group Interactions (PGI), .70 for Institutional and Goal Commitments (IGC), .88 for Interactions with Faculty (IF), .89 for Faculty Concern for Student Development and Teaching (FCSDT). Guttman split half coefficients were found .76 for Academic and Intellectual Development, .78 for Peer-Group Interactions, .63 for Institutional and Goal Commitments, .82 for Interactions with Faculty, .91 for Faculty concern for Student Development and Teaching. Cronbach alpha coefficient was found .93, Guttman split half coefficient was found .89 for all scale.

\section{Participants}

The universe of the study includes all freshmen undergraduate and graduate international students at an American university. Simple random sampling method was used for determining the sample of the research. A total of 181 freshmen undergraduate and graduate international students filled out the Institutional Integration Scales in June 2015. A total of $44.20 \%$ (80) of the students were from China, $15.47 \%$ (28) of them were from South Korea, $15.47 \%$ (28) of them were from India, $2.21 \%$ (4) of them were from Sri Lanka, 2.21\% (4) of them were from Mexico, 2.21\% (4) of them were from Taiwan, 2.21\% (4) of them were from Saudi Arabia, 2.21\% (4) of them were from Nigeria, $2.21 \%$ (4) of them were from Hong Kong, $2.21 \%$ (4) of them were from Japan, $4.42 \%$ (8) of them were from Iran, $4.97 \%$ (9) of them were from Vietnam. $24.86 \%$ (45) of them were female and $75.14 \%$ 
(136) of them were male. $55.80 \%$ (101) of them were undergraduate students, and $44.20 \%$ (80) of them were graduate students.

A total of $49.72 \%$ (90) of the students were enrolled in engineering, $2.21 \%$ (4) of them in archeology, $2.21 \%$ (4) of them in psychology, $2.21 \%$ (4) of them in architectural design, $7.18 \%$ (13) of them in economy, $2.21 \%$ (4) of them in beauty, 9.39\% (17) of them in education, $5.52 \%$ (10) of them in business, $5.52 \%$ (10) of them in urban planning, $4.97 \%$ (9) of them in physics, $4.42 \%$ (8) of them in mathematics, $2.21 \%$ (4) of them in biology, $2.21 \%$ (4) of them in the political science department.

\section{Data Collection and Analysis}

After the data collection procedure, multivariate variance analysis (MANOVA) was done for determining whether the frequency of the students' using the international student center has a relation with the integration level of the international students or not. One way variance analysis (ANOVA) was used for determining whether the frequency of the students' using the international student center relates to their achievement or grade point average (GPA) or not.

Firstly, the extreme values in the data set have been determined in order to meet the assumption of normality from assumptions of ANOVA and MANOVA. For this assumption, the item scores have been converted to standard $\mathrm{z}$ scores and points other than -3 and +3 were determined (Tabachnick \& Fidel, 2007). A total of 32 rows were removed from the data set. The descriptive statistics (skewness and kurtosis) of the GPA and Scale's factor scores according to frequency of using the center were done to determine the univarite normality assumption of ANOVA. These results are presented in Table 1 below.

The skewness and the kurtosis values are used for examining normal distribution of scores. If these scores are between -1 and +1 , the distribution does not deviate from normal excessively (Mertler \& Vannatta, 2005). Skewness and kurtosis values are zero in standard normal distribution. The skewness and kurtosis values in Table 1 were calculated in terms of frequency of using the center. According to Table 1, skewness and kurtosis values of the scale's factor scores are between -1 and +1 . In this instance, the scores do not deviate from standard normal distribution.

Another assumption of ANOVA is the homogeneity of variances. The homogeneity of the variances was checked by Levene $\mathrm{F}$ test to use ANOVA. The variances are equal according to the test result (FGPA = 1.99; 
$\mathrm{p}>.05 ;$ FAID $=.91 ; \mathrm{p}>.05 ;$ FPGI $=.84 ; \mathrm{p}>.05 ;$ FIGC $=1.33 ; \mathrm{p}>.05 ;$ FIF $=$ $1.55 ; \mathrm{p}>.05 ; \mathrm{FFCSDT}=1.02 ; \mathrm{p}>.05)$.

Table 1. Skewness and Kurtosis Values of GPA and Scale's Factor Scores According to Frequency of Using the Center $(\mathrm{N}=181)$.

\begin{tabular}{lcccc}
\hline & Categories & $N$ & Skewness & Kurtosis \\
\hline GPA & 1 & 50 & -.35 & -.85 \\
& $2-9$ & 59 & -.79 & .04 \\
AID & $10<$ & 72 & -.60 & -.39 \\
& 1 & 50 & .20 & -.28 \\
& $2-9$ & 59 & -.28 & .64 \\
PGI & $10<$ & 72 & -.37 & .66 \\
& 1 & 50 & -.32 & .02 \\
& $2-9$ & 59 & -.80 & .44 \\
IGC & $10<$ & 72 & -.74 & .32 \\
& 1 & 50 & .97 & .01 \\
& $2-9$ & 59 & -.94 & .49 \\
IF & $10<$ & 72 & -.66 & .36 \\
& 1 & 50 & -.01 & -.75 \\
& $2-9$ & 59 & -.68 & -.48 \\
FCSDT & $10<$ & 72 & -.18 & -.09 \\
& 1 & 50 & -.08 & -.13 \\
& $2-9$ & 59 & -.24 & -.05 \\
& $10<$ & 72 & -.63 & .25 \\
\hline
\end{tabular}

One of the assumptions that must be provided for MANOVA is multivariate normality. The Bartlett Sphericity Test showing the assumption of multivariate normality was made and found significant (333.68; $\mathrm{p}<.01$ ). According to this result, the data meet the multivariate normality assumption.

Another assumptions that must be provided for MANOVA is the lack of a multiple linear relationship between dependent variables. In order to use MANOVA, dependent variables must be related to each other theoretically (Leech, Barret \& Morgan, 2005). On the other hand, if the relationship between dependent variables is too high (Correlation 
coefficients over .80 or .90 ) it will cause problems in MANOVA (Pallant, 2005). Correlation values were calculated in this study as rAID\&PGI $=.42$; rAID\&IGC $=.58 ;$ rAID\&IF $=.52 ;$ rAID\&FCSDT $=.59 ;$ rPGI\&IGC $=.32 ;$ rPGI\&IF $=.55 ;$ rPGI\&FCSDT $=.43 ;$ rIGC\&IF $=.38 ;$ rIGC\&FCSDT $=.46$; rIF\&FCSDT $=.62$. Accordingly, there are no multiple linear relationships among dependent variables.

Another assumption for the use of MANOVA is homogeneity of variance covariance matrices. The "Box's M" test is used for this. The statistical significance of the Box's M test indicates that the assumption of homogeneity of variance-covariance matrices is provided and the statistical insignificance of the Box's $M$ test suggests that this assumption is violated. The significance of the Box's $M$ test is significantly influenced by the number of participants in the study and the Box's M test can be made much more significant when the number of participants is high. Therefore, the significance level for this test is suggested to be taken as .025, .01 (Mertler \& Vannatta, 2010) or .001 (Pallant, 2005). In this study, the significance level for the Box's M test was taken as .01.

In the study, the significance value for the Box's $M$ test calculated for the dependent variable data set consisting of independent variables shows that the assumption of homogeneity of the variance covariance matrices for the independent variables is met (frequency [Box's $\mathrm{M}=102.78$, $\mathrm{p}>.01])$.

\section{RESULTS}

The first sub-objective of the study is to determine whether the frequency of the students' using the center's orientation training session has a relation with their integration. The Institutional Integration Scales was used for determining the integration level of the international students. The scale includes five factors which are (1) peer-group interactions, (2) interactions with faculty, (3) student development and teaching, (4) academic and intellectual development, and (5) institutional and goal commitments. For this purpose, multivariate variance analysis (MANOVA) was done to find whether the scale's factor scores are different or not based on their (international students) frequency of using the center. Table 2 presents MANOVA results. The results show that the scale's factor scores vary based on the frequency of using the center [Wilks lambda ( $\not \subset$ frequency) $=.10$, $\mathrm{F}(10,348)=75.57, \mathrm{p}<.01]$. 
Table 2. MANOVA Results of the Mean of the Scale's Factor Scores Based on the Frequency of Using the Center

\begin{tabular}{lcccccc}
\hline & Value & $\mathrm{F}$ & $\begin{array}{c}\text { Hypothesis } \\
\mathrm{df}\end{array}$ & Error df & $\mathrm{p}$ & $\eta^{2}$ \\
\hline $\begin{array}{l}\text { Pillai's Trace } \\
\text { Wilks' }\end{array}$ & .93 & 30.25 & 10.00 & 350.00 & .00 & .46 \\
$\quad$ Lambda & .10 & 75.57 & 10.00 & 348.00 & .00 & .69 \\
$\begin{array}{l}\text { Hotelling's } \\
\quad \text { Trace }\end{array}$ & 8.79 & 152.09 & 10.00 & 346.00 & .00 & .82 \\
$\begin{array}{l}\text { Roy's } \\
\text { Largest }\end{array}$ & 8.76 & 306.61 & 5.00 & 175.00 & .00 & .90 \\
$\quad$ Root & & & & & & \\
\hline
\end{tabular}

Table 3. ANOVA Results of the Mean of the Scale's Factor Scores According to Frequency of Using the Center

\begin{tabular}{lccccccccc}
\hline $\begin{array}{c}\text { Dependent } \\
\text { Variable }\end{array}$ & Frequency & $\mathrm{N}$ & $\underline{X}$ & $\mathrm{SD}$ & $\mathrm{F}$ & $\mathrm{df}$ & $\mathrm{p}$ & $\eta^{2}$ & Difference \\
\hline AID & 1 & 50 & 29.86 & 3.63 & 1.06 & 2 & .35 & .01 & \\
& $2-9$ & 59 & 30.51 & 4.51 & & & & & \\
& $10<$ & 72 & 31.01 & 4.58 & & & & & \\
\hline PGI & 1 & 50 & 37.80 & 6.02 & .33 & 2 & .72 & .01 & \\
& $2-9$ & 59 & 36.78 & 6.92 & & & & & \\
& $10<$ & 72 & 37.43 & 6.96 & & & & & 1 and $2-9$ \\
IGC & 1 & 50 & 17.62 & 1.75 & 767.35 & 2 & .00 & .90 & 1 and $10<$ \\
& $2-9$ & 59 & 24.32 & 1.82 & & & & & $2-9$ and $10<$ \\
\hline IF & $10<$ & 72 & 28.82 & 1.11 & & & & & \\
& 1 & 50 & 20.54 & 4.98 & 1.40 & 2 & .25 & .02 & \\
& $2-9$ & 59 & 22.05 & 4.71 & & & & & \\
\hline FCSDT & $10<$ & 72 & 21.65 & 4.83 & & & & & \\
& 1 & 50 & 15.42 & 2.72 & .57 & 2 & .57 & .01 & \\
& $2-9$ & 59 & 15.41 & 2.97 & & & & & \\
\hline
\end{tabular}

In this case, the scale's factor scores vary depending on the frequency of using the center. Also, eta squared, which shows how effective an independent variable on a dependent variable, was examined. Eta squared is interpreted considering the value it receives, if the value is $0.01 \leq \eta 2<$ 0.06 , effect size will be at a low level. When the value is $0.06 \leq \eta 2<0.14$, 
effect size will have a moderate effect. Lastly if the value is $\eta 2 \geq 0.14$, effect size will be at a high level" (Cohen, 1960). Therefore, in this study, the effect of frequency of using the center on the scale's factor scores is at a high level $(\eta 2$ frequency $=.69)$.

ANOVA was done to determine which dependent variables vary based on the frequency of using the center. These results are given on Table 3 . When the scale's factor scores are examined, it can be noticed that only Institutional and Goal Commitments factor varies significantly in terms of the frequency of using the center $[\operatorname{FIGC}(2-178)=767.35, \mathrm{p}<.01]$, although there is no significant difference between the other factors $[\operatorname{FAID}(2 ; 178)=$ $1.06, \mathrm{p}>.05 ; \operatorname{FPGI}(2 ; 178)=.33, \mathrm{p}>.05 ; \operatorname{FIF}(2 ; 178)=1.40, \mathrm{p}>.05 ;$ $\operatorname{FFCSDT}(2 ; 178)=.57, \mathrm{p}>.05]$. Scheffe test from post-hoc tests was used to determine the difference in IGC how it varies depending on the frequency of using the center. The reason of using Scheffe Test is to compare all possible linear combinations. When the number of the groups that are compared is high, the test can control $\alpha$ tolerance and does not pay attention to the assumption that the numbers in the groups should be equal. The test is very strong for handling complicated comparisons (Scheffe, 1999). In this instance, scheffe test shows that there is a difference between IGC scores based on the frequency of using the center. The IGC scores of the students, who benefit from the center once in an academic year, are lower than the scores of the students who benefit from the center 2-9 times and 10 or more times in an academic year. The students, who go to the center and participate in trips, events or activities 10 or more times in an academic year, have higher scores than the other students in terms of Institutional and Goal Commitments based on this result. Also eta square shows that the frequency of using the center has a high effect on IGC scores ( $\eta 2$ frequency $=.90)$.

The second sub-objective of the study is to designate whether the frequency of the students' using the center's orientation training sessions is related with their achievement. For this purpose one way variance analysis (ANOVA) was done to determine if the GPA scores vary or not based on the frequency of using the center. Research results are given in Table 4. Table 4 shows that there is no significant difference between the students' GPA scores and the frequency of using the center [F GPA $(2-178)=.59$, $\mathrm{p}>$.05]. In the other words, the students' GPA scores do not vary based on the frequency of using the center. 
Table 4. ANOVA Results of the GPA Scores of the Students Based on the Frequency of Using the Center

\begin{tabular}{cccccccccc}
\hline $\begin{array}{c}\text { Dependent } \\
\text { Variable }\end{array}$ & Frequency & $\mathrm{N}$ & $\underline{X}$ & $\mathrm{SD}$ & $\mathrm{F}$ & $\mathrm{df}$ & $\mathrm{p}$ & $\eta^{2}$ & Difference \\
\hline GPA & 1 & 50 & 3.48 & .34 & .59 & 2 & .55 & .01 & \\
& $2-9$ & 59 & 3.55 & .33 & & & & & \\
& $10<$ & 72 & 3.51 & .31 & & & & & \\
\hline
\end{tabular}

\section{DISCUSSION AND CONCLUSIONS}

The general purpose of this study was to examine the relation of the orientation training sessions with integrations and achievements of the international students. The two sub-objectives were examined in order to find answers to this general purpose.

The first sub-objective of the study was to determine whether there is a relationship between the frequencies of the students' using the center's orientation training sessions and their integration to the university. The Institutional Integration Scales had been used for determining the integration level of the international students. According to the results, the scale's factor scores vary depending on the frequency of using the center. At the same time, the frequency of using the center influences the scale's factor scores highly. Only the students' institutional and goal commitments factor of the scale varies in terms of the frequency of using the center. In this case, the students who benefit from the center 10 or more times in an academic year have higher institutional and goal commitments. In other words, the students who participate in the center's activities, trips or events, feel more attached to the university. The frequency of using the center is not related to the other factors of the scale. In this case, the students' commitments in terms of peergroup interactions, interactions with faculty, student development and teaching, academic and intellectual development do not vary according to using the center. According to Hwang, Martirosyan, and Moore (2015), international students encounter with psychological, socio-cultural, and academic adjustment. Kaczmarek et al. (1994) similarly found that international students' social adjustment and institutional attachment were low. 
Stress is one of the main problems that international students face during their transition to a new culture (Esentürk-Ercan, 1998). Especially Asian students who study in the U.S., who have socio-cultural integration problems (Li \& Gasser, 2005; Zhang \& Goodson, 2011). Likewise, the students who come from Turkic Republics, Turkic and relative communities to Turkey have integration and communication problems (Can, 1996; Çöllü \& Öztürk, 2009). Hence, the socio-cultural integration problems of the international students affects academic achievement of the students who come from Turkic World to Turkey (Kıroğlu, Kesten, \& Elma, 2010). According to Schartner (2015), as international students have lack of interaction with local students, they have adjustment problems. Also, a lack of contact with the local students results in greater attachment to the community of international students. Therefore, orientation training helps in solving difficulties that new international students face and also assists their adaptation to the new academic system (Althen, 1990). Orientation training has preventive and adaptive functions (Yeşilyaprak, 2005). Hwang, Martirosyan, and Moore (2015) suggested that universities should provide support services to satisfy specific needs of varied groups of international students within the specific campus context.

The second sub-objective of the study was to specify whether the frequency of the students' using the center's orientation training sessions is related to their academic achievement. According to the results, the students' GPA scores did not vary with regard to whether the students benefited from the center frequently or not. A similar study reported that although the use of campus services was significantly higher among international students in a peer program, their academic achievement did not differ from nonparticipants (Quintrell \& Westwood, 1994). Other studies conducted on international student achievement show that although the international students face difficulties such as English proficiency, adaptation to new culture, housing, etc., they could still be academically successful (Berman \& Cheng, 2001; Hartnett, Romcke \& Yap, 2004; Mlynarczyk \& Babbitt, 2002) because of adjusting strategies related to academic skills, motivation, and effort (Stoynoff, 1997). On the other hand, according to Alazzi and Al-Jarrah (2016), Southeast Asian undergraduate students from Malaysia and Indonesia attending universities in northern Jordan experienced academic problems as they had stress from studying abroad, leaving their families behind, fearing whether they can meet academic goals, and losing all that is familiar such as language, culture, 
friends, and food. For this reason, Koç, Avşaroğlu, and Sezer (2004) and Tutar (2002) stated that achievement of the international students who do not receive help from the university is low compared to the international students who benefit from the services of the university. As there is a strong relationship between the international students' writing skill and achievement (Andrade, 2006), the writing center that is one of the international student center's facilities, should be recognized and encouraged, and vigorously promoted for new international students (Sherry, Thomas, \& Chui, 2010). Eze and Inegbedion (2015) suggested that remedial classes should be organized for international students' English language. Such remedial classes may provide opportunities that will improve the socialization of international students. Liu (2016) suggested that host universities should dynamically boost and support a buddy program where international students are matched with an American peer who has been at the university and is living through success for at least one academic year so as to afford a first social support.

Shafaei, Nejati, Quazi, and von der Heidt, (2016) approached reasons of international students' low academic achievement from different aspects. According to their research results, students regulating to the indigenous academic norms reveal significant positive commitments to a host country's academic norms. However, students keeping the norms of their home countries tend to display non-significant attitudes towards host country's academic norms. Hence, they suggested that policy makers need to organize suitable programs to educate international students towards acquainting them with the local academic norms and values. For instance, information sessions, training programs, in-class demonstrations and activities, and seminars focusing on the major policies and their impact on students' academic integrity could be organized by universities.

For future studies, researchers could work with international students in several countries. This research was done in the U.S. and the U.S. has many international students from different countries. The ratio of international students in the U.S. shows that Asian students form the majority of the international student population. In the current research, the majority of the international students were also coming from the Asian countries. As the U.S. culture highly differs from Asian cultures, Asian students struggle with cultural and psychological adaptation problems, homesickness, etc. (Li \& Gasser, 2005). Despite these challenges, Asian students' GPA scores display that they are successful. Further studies that 
examine a relationship between GPA scores, integration to school and the frequency of using international student centers could be done on international students coming from other continents.

\section{ACKNOWLEDGEMENT}

This study is a part of 2219 Tubitak Project titled "The Impact of an International Student Center's Orientation Training Sessions on International Students' Achievement and Integration to University."

\section{REFERENCES}

Alazzi, K., \& Al-Jarrah, A. (2016). Southeast Asian international students adjusting to Jordanian universities: Views from the field. Journal of College Student Development, 57(6), 730-741.

Althen, G. (1990). Orientation of foreign students. NAFSA Field Service Working Paper\# 13.

Andrade, M.S. (2006) International students in English speaking universities. Journal of Research in International Education, 5(2), 131-154.

Annaberdiyev, D. (2006). Türkiye'de eğitim gören Türk Cumhuriyetleri ve Türk üniversite ögrrencilerinin psikolojik yardım arama tutumları, psikolojik ihtiyaçları ve psikolojik uyumlarının bazı değişkenler açısından incelenmesi (Yayımlanmamış yüksek lisans tezi). Ege Üniversitesi, İzmir.

Bass, B. M., \& Avolio, B. J. (1993). Transformational leadership and organizational culture. Public Administration Quarterly, 17, 112-121.

Berman, R., \& Cheng, L. (2010). English academic language skills: Perceived difficulties by undergraduate and graduate students, and their academic achievement. Canadian Journal of Applied Linguistics/Revue canadienne de linguistique appliquée, 4(1), 25-40.

Berry, J. W. (1997). Immigration, acculturation and adaptation. Applied Psychology: An International Review, 46, 5-68.

Can, N. (1996). Türkiye'de yükseköğrenim gören yabancı uyruklu öğrencilerin sorunları ve örgütsel yapı. Erciyes Üniversitesi Sosyal Bilimler Enstitüsü Dergisi, 7, 503-512.

Ceyhan, E. (1995). Oryantasyon eğitimi. Yaşadıkça Eğitim. 42, 14-15.

Chen, C. Y., \& Razek, N. A. (2016). Acculturation and sense of belonging: Engagement patterns for Indian graduate students in the United States. In Allied Academies International Conference. Academy of Educational Leadership. Proceedings, 21(1), 13-17. Jordan Whitney Enterprises, Inc.

Cohen, J. (1960). A coefficient of agreement for nominal scales. Educational and Psychological Measurement, 20, 37- 46. 
Coleman, S., \& Carsky, M. (1994). Responding to cultural differences: An innovative approach to measuring international student satisfaction. International Education, 23, 5-13.

Creswell, J. W. (2012). Educational research: Planning, conducting, and evaluating quantitative and qualitative research (4th ed.). Boston, MA: Pearson Education, Inc.

Creswell, J. W. (2014). Research design: Qualitative, quantitative, and mixed methods approaches. Thousand Oaks: Sage publications.

Çöllü, E. F., \& Öztürk, Y. E. (2010). Türk Cumhuriyetleri, Türk ve akraba topluluklarından Türkiye'ye yüksek öğrenim görmek amacıyla gelen öğrencilerin uyum ve iletişim sorunları (Konya Selçuk Üniversitesi Örneği). Journal of Azerbaijani Studies, 11(1- 4), 223-239.

Esentürk-Ercan, L. (1998). Yabancl uyruklu ve Türk üniversite ögrencilerine ait sorunların bazı değişkenler açısından incelenmesi (Yayımlanmamış doktora tezi). Hacettepe Üniversitesi, Ankara.

Eze, S. C., \& Inegbedion, H. (2015). Key factors influencing academic performance of international students in UK universities: a preliminary investigation. British Journal of Education, 3(5), 55-68.

Fraenkel, J. R., \& Wallen, N. E. (2000). How to design \& evaluate research in education (4th ed.). Boston: McGraw Hill.

Gareis, E. (2012). Intercultural friendships: Effects of home and host region. Journal of International and Intercultural Communication, 5, 309-328. doi:10.1080/17513057.2012.691525

Hartnett, N., Romcke, J., \& Yap, C. (2004) Student performance in tertiary-level accounting: An international student focus. Accounting and Finance, 44, $163-85$.

Hayes, R. L., \& Lin, H. (1994). Coming to America: Developing social support systems for international students. Journal of Multicultural Counseling and Development, 22, 7-16. doi:10.1002/j.2161-1912.1994.tb00238.x

Henriksen, J.A.S. (1995). Orientation and counseling in a California Community College: Surveying the perspectives of a multicultural student population. Community College Review, 23(2), 59-74.

Hwang, E., Martirosyan, N. M., \& Moore, G. W. (2015). A Review of literature on adjustment issues of international students: Recommendations for future. Global Perspectives and Local Challenges Surrounding International Student Mobility, 223.

Institute of International Education. (2013). International students at all institutions, 2001/02-2012/13. Retrieved from http://www.iie.org/opendoors 
Johnson, L. R., \& Sandhu, D. S. (2007). Isolation, adjustment, and acculturation issues of international students: Intervention strategies for counselors. In H. Singaravelu \& M. Pope (Eds.), A handbook for counseling international students in the United States (pp. 13-35). Alexandria, VA: American Counseling Association.

Kağıtçıbaşı, C. (2000). Kültürel psikoloji: kültür bağlamında insan ve aile. İstanbul: Evrim Yayınevi.

Kaczmarek, P. G., Matlock, G., Merta, R., Ames, M. H., \& Ross, M. (1994). An assessment of international college student adjustment. International Journal for the Advancement of Counselling, 17(4), 241-247.

Kiliçlar, A., Sari, Y., \& Seçilmis, C. (2012). Türk dünyasindan gelen ögrencilerin yasadiklari sorunlarin akademik basarilarina etkisi: Turizm ögrencileri örnegi. Bilig, 61, 157-172.

Kıroğlu, K., Kesten, A., \& Elma, C. (2010). Türkiye'de öğrenim gören yabancı uyruklu lisans öğrencilerinin sosyo-kültürel ve ekonomik sorunları. Mersin Üniversitesi Ĕgitim Fakültesi Dergisi, 6(2), 26-39.

Koç, M., Avşaroğlu, S., \& Sezer, A. (2004). Üniversite öğrencilerinin akademik başarıları ile problem alanları arasındaki ilişki. Selçuk Üniversitesi Sosyal Bilimler Enstitüsü Dergisi, 11, 483-498.

Komiya, N., \& Eelss, G. T. (2001). Predictors of attitudes toward seeking counseling among international students. Journal of College Counseling, 4, 153-160. doi:10.1002/j.2161-1882.2001.tb00195.x

Korkmaz, A. (2000). Yükseköğretim gençliğinin problemleri. Milli Eğitim Dergisi, 145, 41-45.

Kuo, W. H., \& Tsai, Y. M. (1986). Social networking, hardiness and immigrant's mental health. Journal of Health and Social Behavior, 27, 133-149. doi: $10.2307 / 2136312$.

Leech, N.L. Barlett, K.C. \& Morgan, G.A. (2005). SPSS for intermediate statistics; use and interpretation. Mahwah, NJ: Lawrence Erlbaum Associates.

Li, A., \& Gasser, M.B. (2005). Predicting Asian international students' socio cultural adjustment: A test of two mediation models. International Journal of Intercultural Relations, 29(5), 561-576.

Liu, D. (2016). Strategies to promote Chinese international students' school performance: resolving the challenges in American higher education. AsianPacific Journal of Second and Foreign Language Education, 1(1), 8.

Guidry Lacina, J. (2002). Preparing international students for a successful social experience in higher education. New Directions for Higher Education, 117, 21-28.

Mertler, C. A., \& Vannatta, R. A. (2002). Advanced and multivariate statistical methods. Los Angeles, CA: Pyrczak.

Mlynarczyk, R.W., \& Babbitt, M. (2002). The power of academic learning communities. Journal of Basic Writing, 21(1), 71-89. 
Mori, S.C. (2000). Addressing the mental health concerns of international students. Journal of Counseling \& Development, 78(2), 137-144. DOI: $10.1002 / \mathrm{j} .1556-6676.2000 . t b 02571 . x$.

Pallant, J. (2005). SPSS survival Manual: A step by step guide to data analysis using SPSS for Windows. Australia: Australian Copyright.

Pascarella, E. T., \& Terenzini, P. T. (1980). Predicting freshman persistence and voluntary dropout decisions from a theoretical model. The Journal of Higher Education, 51(1), 60-75.

Pedersen, P.B. (1991). Counseling international students. The Counseling Psychologist, 19(1), 10-58. DOI: 10.1177/0011000091191002.

Polat, F. (2012). Türkiye'de öğrenim gören yabancı uyruklu ilköğretim ögrencilerinin karşılaştıklarl sorunlar ve çözüm önerileri (Unpublished master's thesis). Furat Üniversitesi, Elazığ.

Quintrell, N., \& Westwood, M. (1994). The influence of a peer pairing program on international students' first year experience and use of student services. Higher Education Research and Development, 13(1), 49-58.

Schartner, A. (2015). You cannot talk with all of the strangers in a pub: A longitudinal case study of international postgraduate students' social ties at a British university. Higher Education, 69(2), 225-241.

Sherry, M., Thomas, P., \& Chui, W. H. (2010). International students: A vulnerable student population. Higher education, 60(1), 33-46.

Scheffe, H. (1999). The analysis of variance (Vol. 72). John Wiley \& Sons.

Shafaei, A., Nejati, M., Quazi, A., \& von der Heidt, T. (2016). 'When in Rome, do as the Romans do'Do international students' acculturation attitudes impact their ethical academic conduct? Higher Education, 71(5), 651-666.

Stoynoff, S. (1997). Factors associated with international students' academic achievement. Journal of Instructional Psychology, 24(1), 56.

Tabachnick, B.G. \& Fidell, L.S. (2007). Using multivariate statistics. Boston, Pearson Education, Inc.

Terenzini, P. T., Lorang, W. G., \& Pascarella, E. T. (1981). Predicting freshman persistence and voluntary dropout decisions: A replication. Research in Higher Education, 15(2), 109-127.

Traş, Z. \& Güngör, H.C. (2011). Avrupa ülkelerinden gelen Türk asıllı üniversite öğrencilerinin sosyal destek ve sosyal bağlllıkları üzerine nitel bir araştırma. Selçuk Üniversitesi Sosyal Bilimler Enstitüsü Dergisi, 25, 261-271.

Tinto, V. (1975). Dropout from higher education: A theoretical synthesis of recent research. Review of Educational Research, 45, 89-125.

Tutar, H. (2002). Türk Cumhuriyetleri ve akraba topluluklarindan gelen ögrencilerin başarısızlık nedenleri (Unpublished master's thesis). Kırıkkale Üniversitesi, Kırıkkale. 
Yeşilyaprak, B. (2005). Eğitimde rehberlik hizmetleri. Ankara: Nobel Yayınc1lı.Bass, B. M. (1985). Leadership and performance beyond expectations. New York, NY: Free Press.

Zhang, J., \& Goodson, P. (2011). Predictors of international students' psychosocial adjustment to life in the United States: A systematic review. International Journal of Intercultural Relations, 35(2), 139-162.

MELTEM ACAR GÜVENDIR, $\mathrm{PhD}$, is a professor of education. Assistant Professor, measurement and evaluation in education, educational statistic, science methods. Email: meltemacar@gmail.com

Manuscript submitted: September 9, 2016

Manuscript revised: November 13, 2016 Accepted for publication: January 19, 2017 